range in June at Bombay than at Madras. To investigate this point it will be desirable to give the comparative ranges for the various elements for the various months at the two stations. This is done in the following table.

TABLE III.-Ranges for the Various Months of the Diurnal Variations of the Three Elements at the Two Stations

\begin{tabular}{|c|c|c|c|c|c|c|c|}
\hline \multirow[b]{2}{*}{ Month } & \multicolumn{4}{|c|}{ Bombay } & \multicolumn{3}{|c|}{ Madras } \\
\hline & & $\begin{array}{c}\text { Declina. } \\
\text { tion }\end{array}$ & $\begin{array}{l}\text { Hor. } \\
\text { force }\end{array}$ & $\begin{array}{l}\text { Vert. } \\
\text { force }\end{array}$ & $\begin{array}{l}\text { Declina- } \\
\text { tion }\end{array}$ & $\begin{array}{l}\text { Hor. } \\
\text { force }\end{array}$ & $\begin{array}{l}\text { Vert. } \\
\text { force }\end{array}$ \\
\hline January & $\cdots$ & 162 & 389 & 167 & 9 I & I 318 & 3414 \\
\hline February & $\ldots$ & 117 & 507 & 120 & 64 & 1585 & 3778 \\
\hline March & $\ldots$ & 263 & $57 \mathrm{I}$ & 175 & IO4 & 1785 & 4847 \\
\hline April ... & $\ldots$ & 392 & 576 & 216 & 218 & 1851 & 6273 \\
\hline May ... & $\ldots$ & 486 & 473 & 265 & 243 & 1522 & 4198 \\
\hline June ... & $\ldots$ & 480 & 434 & 257 & 260 & I 2 I 4 & 2917 \\
\hline July ... & $\ldots$ & 468 & 439 & 263 & 249 & 1218 & 244 \\
\hline August & $\ldots$ & 545 & 423 & 301 & 273 & I IOI & 320 \\
\hline September & & 550 & 407 & 365 & 282 & I 33 I & 6401 \\
\hline October & $\ldots$ & $25^{8}$ & 437 & 213 & I IO & I 595 & 516 \\
\hline November & $\cdots$ & 103 & 414 & $9 \mathbf{I}$ & 73 & 1362 & 363 \\
\hline December & $\ldots$ & 136 & 356 & 89 & 86 & $\mathrm{III}_{4}$ & 2280 \\
\hline
\end{tabular}

From this table it will be seen that for both stations there is a smaller maximum of declination range about May or June, and a larger maximum in September, while the most decided minima are in November and February for both stations. Again, there is a maximum of horizontal force range for both stations in April, and also in October while the minima are at Bombay in September and December, and at Madras in August and December.

Finally, at Bombay there is a smaller maximum of vertical force range in May and a larger in September, while at Madras these occur in April and September. The most pronounced minimum of vertical force is in December for both stations.

It would thus appear that there is a very striking likeness between the variations of the three elements at the two stations, and that, notwithstanding Mr. Pogson's remark about the vertical force instrument, its results do not appear to be without value in a comparison of the above nature.

BALFOUR STEWART

\section{PLANTS AND THEIR DEFENCES}

$A$ CONSTANT struggle for existence, the consequence A the enormous increase in the numbers of the every organism, both animal and vegetable. Some have to sustain the attacks of others which are directly antagonistic to them, and which regard them as prey; in the case of others the struggle is rather one to live in the face of adverse conditions or peculiarities of environment, so that the different organisms are not directly hostile, but each affects its neighbour injuriously by adapting itself more readily to the changing surroundings, and so diminishing the other's power of obtaining nutriment, sunlight, or whatever other condition may be the object of their competition. Thus have been developed in the different competitors different features of their constitution-many perfecting powers of active assault, others facilities for active or passive defence. The lastnamed is particularly the feature found in the vegetable kingdom. The want of locomotion prevents any aggressive movement of the individual, and hence success in the struggle can only be secured by more complete adaptation to environment than its competitors can show, or by protective mechanisms guarding the individual from the assaults of organisms inclined to prey upon it. These mechanisms exhibit very great variety, and their object often seems obscure till they are looked at in the light of the environment of the plant, the conditions of its life, and the enemies against which it has to contend. The specially-exposed points of attack are three: the succu- lent leaves and shoots or the attractive fruits are assailed by animals in search of food; the honey secreted by the flower to allure to it the particular insect adapted to bring about properly the process of fertilisation attracts also other insects whose presence is useless for such purpose, and which therefore are only robbers ; while the fertilising pollen is itself the object of desire on the part of others which are equally unable to apply it to its legitimate purpose.

The protective mechanisms of plants, therefore, so far as they are directed against aggressive animals, are to be looked for mainly in the neighbourhood of the young growing parts or the reproductive organs. Not exclusively, however, but generally the older vegetative parts are defended by their own inherent qualities, such as their hardness or wiriness, which keep them from being suitable for the food of their assailants. Such young growing parts in many plants, particularly those growing in exposed regions, are plentifully supplied with thorns, spines, or prickles, rendering them in many cases extremely formidable. The thorns or prickles may be produced on almost all the vegetative organs, and may be merely epidermal structures, or much stronger in composition, containing considerable developments of woody tissue. These thorny plants are most noteworthy in desert countries, some that are met with there, notably the so-called "wait-a-bit" thorn of Africa, having spines of immense length, and being quite impenetrable by man or beast. Cases are not of infrequent occurrence where even the lion himself is a considerable sufferer by coming into collision with this plant. So great is the development of the thorny character in this region that Grisebach connects it particularly with desert exposure and scarcity of vegetation. Nor are thorny plants by any means confined to such regions - on our own heaths the gorse is a familiar plant, and one sufficiently formidable to passers-by ; while other spiny Leguminosæ, as the wrest-harrow (Ononis spinosa), are not infrequent by the wayside. A further peculiarity may be noted in connection with these plants : often the thorns do not occur above the point which is assailable by the animal in its search for food; while, when the shoot has outlived its period of succulent condition, and its tissues have become hard and dry, the thorns do not persist, being much more numerous when the part is young.

Nor is this spiny habit confined to shrubs or trees. The cactuses, which are so remarkable a feature of the vegetation of America, are equally well protected. Their surfaces show great variety of development in this particular: some have small groups of thick rigid spines, others long flexible needles of intense sharpness, penetrating easily the skin of the assailant, and almost impossible to extract.

More formidable defences even than thorns or prickles are found in the varieties of stinging hairs borne so plentifully on the leaves of many plants. These are represented in England by the two species of stinging nettle, which are, as every one knows, capable of producing considerable discomfort to the unwary person who handles them. These are, however, not worth mentioning by the side of many of their tropical relations. The structure of the hair in all these is similar : a mass of cells forms a kind of swollen cushion below; on this is seated the long tapering hair, which ends in a somewhat recurved point or hook. The walls of the upper part of the hair are very strongly silicified, and are, consequently, easily ruptured. Lower down there is but little silica. When touched or rubbed by the hand, the pressure drives the hair downward; at the same time the brittle hook penetrates the skin and breaks off. The downward pressure forces out from the broken hair a fluid of intensely acrid nature, which, on entering the wound made by the point, sets up more or less severe inflammation. This fluid is generally conjectured to be formic acid-a 
view based on the fact that this acid can be obtained from the nettle plant by suitable means.

While the English representatives of this group of plants are sufficiently formidable to careless intruders, some of their connections in other parts of the globe are distinctly dangerous. A traveller in Australia describes a specimen of Urtica gigas in the following terms :- "A specimen seen by Sir W. McArthur, still in full vigour, rises from its base by a series of buttresses of singularly regular outline, gradually tapering, without a branch, to a height of $\mathrm{I} 2 \mathrm{O}$ to $\mathrm{I} 4 \mathrm{O}$ feet. The trunk then divides into a regularly-formed, wide-spreading head, which excites admiration from its extraordinary size. But the ordinary elevation of this tree is 25 to 50 feet, with a circumference of 12 to 20 feet. The leaves, when young and in vigorous growth, attain a breadth of 12 to 15 inches, and are of a beautiful dark-green colour. As may be expected, the poisonous fluid secreted from the foliage is very powerful, particularly in the younger leaves, and their sting is exceedingly virulent, producing great suffering, not unattended with danger. It is found in the northern part of New South Wales, and is a great impediment to the traveller." An Indian species (Urtica or Laportea crenulata) is equally obnoxious. It has rather large leaves, round which numerous small stinging hairs are placed. At certain seasons it emits when bruised so irritating an aroma as to cause a copious flow of saliva and mucus from the nose and eyes for many hours, while violent fevers have been caused by the fluid poured out from its ruptured hairs. Urtica urentissima, a Timor species, which is known to the natives by the significant appellation of "devil's leaf," has been known to produce effects so violent as to last twelve months, and has in some cases even caused death. Malpighia urens bears on its leaves hairs $1 \frac{1}{2}$ inch long, which are pressed flat along the surface. These act very similarly to those of Urtica.

The Loaseæ, or Chili nettles, exhibit similar defences, their power of stinging being very severe.

Other plants are protected also by hairs, which play rather a mechanical than a chemical part. Such are various species of Deutzia, particularly D. scabra, which bears on its leaves numerous star-shaped hairs whose walls are permeated with silica.

Besides these defences, which are chiefly mechanical, though in the case of the nettle a secretion acting chemically plays an important part in their behaviour, many plants are protected by chemical means alone. This is seen chiefly, though by no means exclusively, in the case of flowers and frtit. The plant secretes in different parts, or it may be throughout its system, a juice which may be poisonous, or acrid, or harmless in effect, but very unpleasant to its assailant. Thus very many of the Solanaceous plants have poisonous fruit, as Atropa Belladonna and some species of Solanum. The whole plant is charged with juice of great pungency in many of the Ranunculaceæ, $R$. sceleratus causing sores if allowed to come into contact with a delicate mucous membrane such as that of the mouth. Parts of the Aconite (A. Napellus) are intensely poisonous, while the seeds of Strychnos Nuxvomica yield the well-known drug strychnine. Others have a latex or juice which is intensely bitter and unpleasant to the taste, as the different species of spurge (Euphorbia), the dandelion, the wild lettuce, different species of poppy, and many others. An acrid juice is to be met with in many Cruciferæ, as the mustard and the radish. The aromatic Umbelliferæ, also, are protected in this way from many of their enemies, the peculiar flavour which they possess being very unpalatable to many birds which are attracted by their fruits. Other plants pour out resinous and other sticky secretions which serve the sanie purpose. Some others are protected by the possession of a.very fœtid odour, much resembling putrefying animal matter, though this has probably been developed to attract the carrion-loving flies which secure cross-fertilisa- tion of the plants. Such are Arum Dracunculus and Stapelia, a genus of Asclepiadaceæ.

A very different kind of defence against intruders is found in a Sumatran parasite, Hydriophytum formicarum. This plant, instead of developing special weapons of its own, attracts to itself a colony of ants whose sting is very severe. These resent very effectually the attacks of animals inimical to the plant. It is described as parasitic on trees in the form of a large irregular tuber, fastening itself to them by fibrous roots, and throwing out several branches above. The tuber is generally inhabited by ants, and is hollowed out by them into numerous winding passages, which frequently extend a good way along the branches also, giving them the appearance of being fistular. A similar arrangement is found in Acacia spharocephala, but a more elaborate one, as the plant not only serves as a habitation for the ants, but derelops certain organs to attract them to it. The stem and branches are furnished with very large thorns, which are set along them in pairs. The thorns are enormously swollen at their bases, which are hollow, and in these swellings the nests of the ants are found, the magnitude of the enlargement being no doubt caused by the irritation of the insects. At the base of each pair of thorns, about midway between the two, is found a large nectar-secreting gland, which is very active. The leaves of the plant are pinnate, and on the leaflets are numerous small pear-shaped glands, consisting of delicate masses of cells containing an oily secretion. Cecropia is also protected in the same way; its stem is hollow, and contains the nests of the ants. As in the case of the Acacia, glandular structures are present, which attract the ants and afford them food. Schomburgk describes a plant belonging to the order Polygonaceæ (Triplaris Schomburgkiana), a native of Guiana, as having its trunk and branches hollow between the nodes, and serving as the habitation of venomous ants. He also mentions an orchis (Schomburgkia tibicinis), which, he says, has pseudo-bulbs arising from creeping root-stocks. These have a small hole at their base, and ants and other insects construct their nests therein.

Turning more especially to the reproductive organs of plants, we find them attractive to intruders, not only on account of their own palatability or succulence, but as providing two especial delicacies much sought after by the insect world-honey or nectar, and pollen. The object of the secretion of the former is to secure the due transference of the latter from the stamen of one flower to the pistil of another, and this is effected in most cases by some particular insect. The invasion of others would hence lead to loss of honey or pollen, or both, without securing the end aimed at. It is natural, therefore, to expect to find many contrivances to secure the secretion to the appropriate insect, and an almost infinite variety is found, some mechanical, others chemical, others partaking of the nature of both. The enemies most guarded against are those insects which we have seen in some other plants especially courted-ants. In assailing the plant they must usually ascend the stem from the ground, and many and various are the pitfalls placed in their way. In the teasle, the leaves, arranged in pairs along the stem, have their bases attached to it and to one another, forming deep cups, which are filled with water, thus presenting an obstacle to their ascent. The leaves of the pine-apple are arranged to bring about the same result. Some plants are surrounded in their growth by water, as many of the Polygonaceæ. In P. amphibium, which grows sometimes in water, and sometimes on land and has two characteristic forms accordingly, the land form has developed round the flower-stalks a number of sticky glands, while the water form has nothing of the sort. The two forms are protected from the ants, but by different means. Silene, the catchfly, and Circea, the enchanter's nightshade, also are examples of plants furnished with sticky glands. Lactuca, the wild lettuce, emits 
a milky juice on being assailed by them. Other plants, as some varieties of the willow, have very slippery flowerstalks, which the ants cannot pass along. The forms of the flower, too, lend themselves to protective purposes: thus Antirrhinum and Linaria have a close-shutting corolla, which they cannot enter; Cobora is furnished with free hairs growing on the corolla, which block the way to the nectar, and which are insurmountable by the insects Where such means are not found, in some cases a counterattraction is provided to draw the unwelcome visitors to parts where their attentions will be harmless: thus Impatiens has honey-glands on the leaves which are said to stop the ants on their way to the flower.

Other insects than ants are also to be guarded against. Many flowers are capable of fertilisation by more than one species of insect, but others are especially adapted only to one kind. In these the form of the flower, while affording facilities for the proper insect to receive its pollen upon the proper region of its body, also presents obstacles to others which would be useless. The peculiar construction of the corolla in such cases serves as a protection to both nectar and pollen. This may be carried still further, access to the honey by other than the appropriate channel being hindered by chemical means. An instance of this is seen in the Alpine varieties of the Aconite, which are adapted for fertilisation by bees. Instead of the insect inserting its proboscis into the flower from the front, so as to make it pass the stamens and pistil, one bee (Bombus mastrucatus) bites a hole in the back of the hood formed by the sepals, and abstracts the honey. The white variety of the flower is unprotected against the theft, but the other, blue in colour, has a nauseous, bitter taste, and so is let alone.

Besides meeting the attacks of animals in these different ways, plants have to cope with other dangers, and require for these another system of defences, which are more associated with peculiarities of environment. They are assailed continually by varying conditions of climate and temperature, and have in many cases very curious modification; of structure and habit to correspond with these. A danger that threatens most plants, except in a few regions of the world, is that of having their pollen injured by rain. To meet this many varieties of form of corolla have been developed. Many have a long narrow tubular shape, the claws of the petals cohering together, while the free limbs can curve outwards in fine weather, but arch over the tube when wet. Others have a campanulate form, with the base of the bell upwards, so that rain falling on the flower cannot get near the stamens, but is shot off as by a roof. In others the stamens are covered over by development of another part of the flower, as in the Iris; the filament of the stamen, too, may be broad, and bear the anther on its under surface, as in the Naiadaceæ. It is rather curious that flowers that produce large quantities of pollen have not such defences against this clanger as those which form but little, while the most complete adaptations are found in the cases of plants that inhabit damp climates.

Many flowers are defended by habit rather than structure. In wet weather they do not open their corollas at all, and not a few, even in fine weather, keep open for a very little while, only a few hours in many cases.

Besides rain, other meteorological conditions are fraught with danger. One of the most commonly occurring is frost ; and allied to this is the loss of heat by radiation during the night. The power of resistance to these conditions varies very much, but in many whose constitution makes them peculiarly susceptible to damage thereby there has been developed the so called power of sleep. The term is no doubt a misnomer, but it has been adopted and associated with certain well-defined movements which the leaves of the plants perform at the close and at the beginning of day. The movements differ very greatly with different plants, but they bring about such a position of the leaves as will protect the upper surface from radiation. Some of them are of a very complex nature, particularly those shown by certain of the Leguminosæ, which have pinnate leaves. It is in this natural order that the property of sleep is most prevalent, certain of the Oxalidaceæ and their allies coming next to them.

A similar mechanism protects very many plants from excess of sunlight, which is injurious to the chlorophyll. In bright sunshine the leaves assume a position which has been called "diurnal sleep." In it they present their edges and not their faces to t'se light. In other leaves the chlorophyll corpuscles themselves move, taking up a position on the lateral walls of the cells rather than on the front ones, or so placing themselves that their profile and not their surface is exposed to the sun. In some of the Algæ, as Mesocarpus and Vaucheria, this sensitiveness is seen.

Other protective devices may be seen by studying the adaptations of plants to their conditions of life. Thus the leaves of submerged plants are preserved from being broken by the currents of water by being minutely subdivided, so that they adapt themselves easily to the motion, and do not oppose a resistance. Desert plants are protected from drought by the development of a succulent habit. Aërial parts of plants, again, are protected in many cases from becoming moistened by water by a deposition in the cuticular layers of the epidermis of varying amounts of wax or resin.

\section{THE ORIGIN OF OUR POTATO}

$\Upsilon \mathrm{HE}$ year $\mathrm{I} 886$, by its tercentenary associations, brings once before us the subject of the introduction of the potato into our islands, but brings it still with most of the connected questions unsolved.

How, and when, and whence it was brought was considered by Banks in 1808 , and it was by him attention was drawn to a manuscript statement in 1693 by Dr. Southwold Smith, F.R.S., that his grandfather received it from Sir Walter Ralegh, and sent it to Ireland.

It was considered by Sabine in 1822 , when he concluded a paper before the Royal Horticultural Society with the remark, "The introduction of the potato into Virginia is still involved in obscurity."

It has been considered by De Candolle in his "Géogr. Bot. Raisonée" in 1855 , and more recently in his "Origin of Cultivated Plants" in I882. It has also been considered by others. While of the old unanswered questions some are now regarded as of mere antiquarian interest, there are others to which greater importance is attached than there ever has been before.

Among the latter a fresh interest has been given by Mr. Baker's paper before the Linnean Society in January, I884, to the old question, was it $S$. tuberosum that was introduced from Virginia? The suggestion he, in conjunction with Earl Cathcart, has thrown out, that to strengthen our cultivated potato against disease we should cross with some other species of tuber-bearing Solanum, makes it important we should clearly know what is the species we have been for 300 years cultivating. There are many other questions surrounding the consideration, some of which border on that fundamental question, What constitutes a species?

That simple but highly practical method of approaching the question, "What is our species?" the method of introducing supposed distinct wild species, and watching their changes from year to year in cultivation, has not yet been followed sufficiently long, nor with a sufficient number of such species to effect much more than establish well-founded hopes that by it there is much we-may Jearn. At present the twenty (?) years' cultivation of $S$. maglia is the only experiment on which we can rely. What conclusions such experiments may eventually lead $\mathrm{s}$ to it is impossible to predict, but this is certain, that 